\title{
Pd-Catalyzed Substitution Reactions with Organoindium Reagents in situ Generated from Indium and Allyl or Propargyl Halides
}

\author{
Phil Ho Lee, Eunkyong Shim, Kooyeon Lee, Dong Seomoon, and Sundae Kim

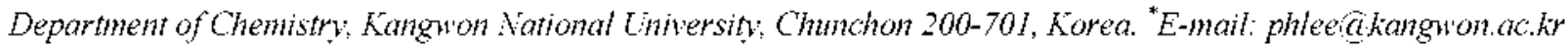 \\ Received lovember 20, 2004
}

\begin{abstract}
Allylindium and propargylindium reagents in sitt generated from the reactions of indium with allyl halides and propargyl halides could participate as nucleophiles in Pd-catalyzed substitution reactions of allyl carbonates to produce 1.5-dienes and 1.5-enynes in good yields. $\beta$-Hydride elimination products were produced in case of carbonates having $\beta$-hydrogens. Because organoindium reagents obtained from allyl or propargyl halides and indium have previously not been used to Pd-catalyzed allylic and propargylic substitution reactions. these results should provide more opportunities for the development of new C-C bond forming reactions.
\end{abstract}

Key Words : Allylation. Propargylation. Indium. Palladium, Substitution

\section{Introduction}

The Pd-catalyzed mucleophilic substitution reactions of allyl esters and carbonates with a variety of nucleophiles are very important transition metal-catalyzed processes. ${ }^{l}$ Although the stabilized carbanions ${ }^{2}$ and various transmetalating agents (Sn. Al, $\mathrm{Zr}, \mathrm{Li}$, and $\mathrm{Mg}$ ) ${ }^{3}$ have been reported for metalcatalyzed nucleophilic substitution reactions. development of easily available ally' and propargy'l transmetalating agents is still needed due to further functionalization of $\mathrm{C}-\mathrm{C}$ multiple bonds in products. ${ }^{+}$The use of allyl- and propargy $1-$ stannanes as coupling partners has attracted much attention as a result of their availability and air- and moisture-stability. as well as compatibility with a variety of functional groups. Preparation of allyl- and propargylstamnanes is generally accessible. whereas such procedures are sometimes inadequate and the requisite allylmetals and propargylmetals are difficult to obtain. Ideally ally lmetals and propargylmetals must be prepared in situ from the reaction of metals with allyl and propargyll halides. The major advantage of organomagnesium and organolithium compounds as coupling partners is their availability. However these reagents show low functional group tolerance and $\beta$-hyddride eliminations occurred due to their basicity. Therefore. the development of new ally'metals and propargy'metals in Pd-catalyzed nucleophilic substitution reactions was explored to overcome these difficulties. Our interest applying indium metal to organic synthesis ${ }^{7}$ has led us to investigate the participation of indium organometallics in metal-catalyzed reactions. ${ }^{8}$ In this paper we report that in situ generated allylindium and propargylindium reagents can be applicable to allylic and propargylic substitution reactions of allyl carbonates catalyzed by $\mathrm{Pd}(0)$ as nucleophiles (Scheme 1$)^{9}$

\section{Results and Discussion}

Reactions of Allyl Carbonates with in situ Generated Allylindiums from Indium and Ally Halides. At the outset. the catalytic activity of several palladium complexes was examined in the reaction of trans-cinnamyl methyl carbonate with allylindium. which was in situ generated from the reaction of allyl bromide and indium. Among the cataly'sts studied. $1 \mathrm{~mol} \%$ of $\mathrm{Pd}_{2} \mathrm{dba}_{3} \mathrm{CHCl}_{3}$ showed high catalytic activity. Other palladium complexes. such as $\mathrm{Pd}\left(\mathrm{CH}_{3} \mathrm{CN}\right)_{2} \mathrm{Cl}_{2}, \mathrm{Pd}(\mathrm{PhCN})_{2} \mathrm{Cl}_{2} . \mathrm{PdCl} \mathrm{l}_{2} . \mathrm{BnPd}\left(\mathrm{PPh}_{2}\right)_{2} \mathrm{Cl}$, and $\mathrm{Pd}\left(\mathrm{PPh}_{3}\right)_{4}$ produced trans-1-phenyl-1.5-hexadiene in low yields. Among the ligands studied, tri- $o$-tolylphosphine gave the best results. Of the catalytic systems examined. the best results were obtained with 1 mol \% of $\mathrm{Pd}_{2} \mathrm{dba}_{3} \mathrm{CHCl}_{2}$ and 8 mol \% of $(o \text {-Tolyl })_{2} \mathrm{P}$ in THF at $65^{\circ} \mathrm{C}$ under a nitrogen atmosphere, producing l-phenyl-1.5-hexadiene in $90 \%$ y ield with regioselectivity. Also, allylindium reagent obtained from the reaction of 1 equiv of indium with 1.5 equiv of allyl bromide gave the best result as a coupling partner. The use of less than 1 equiv of indium and less than 1.5 equiv of allyl bromide resulted in sluggish reaction and gave lower yields.

To demonstrate the efficiency and scope of the present method. we applied this catalytic system to a variety of allyl halides and allyl carbonates. The results are summarized in Table 1. For the allyl halides as precusor of nucleophile. the presence of various substituents at the $\alpha$ and $y$ position effected on product yields. When allylindium derived from

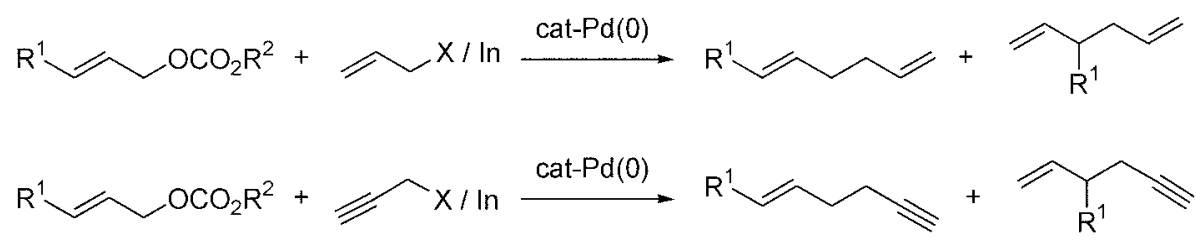

Scheme 1 
Table 1. Pd-catalyzed allylic substitution reactions of allyl carbonates with allylindium reagents

\begin{tabular}{|c|c|c|c|c|}
\hline Entry & Allyl Carbonates & Allyl Halides & Products & Yield $(\%)^{p}$ \\
\hline l & $\mathrm{Ph} \curvearrowright \mathrm{OCO}_{2} \mathrm{Me}$ & & & 80 \\
\hline 2 & & & & 90 \\
\hline 3 & & & & $83(1: 1)^{b}$ \\
\hline 4 & & $\mathrm{EtO}_{2} \mathrm{C}$. & & 44 \\
\hline 5 & & & & $81^{c}(4: 1)^{b}$ \\
\hline 6 & & & & $81^{d}(2.5: 1)^{h}$ \\
\hline 7 & & & & $57^{\circ}(2: 1)^{t}$ \\
\hline 8 & $\mathrm{Ph}$ & & & 78 \\
\hline 9 & & & & 90 \\
\hline 10 & & & & $84(1.4: 1)^{e}$ \\
\hline
\end{tabular}

"Reactions performed in the presence of $1 \mathrm{~mol}^{0} \mathrm{i}$ of $\mathrm{Pd}_{2} \mathrm{dba}_{3} \mathrm{CHCl}$ s and $8 \mathrm{~mol}{ }^{0} \mathrm{o}$ of $(o \text {-Tolyl })_{3} \mathrm{P}$ in THF at $65^{\circ} \mathrm{C}$. unless otherwise noted. "Isomeric ratio ${ }^{c}\left[2.6-(\mathrm{MeO})_{3} \mathrm{Ph}\right]_{3} \mathrm{P}$ was used as ligand. " $\mathrm{Ph}{ }_{3} \mathrm{As}$ was used as ligand. "Diastereomeric ratio.

the reaction of allyl iodide with indium reacted with transciunamyl methyl carbonate in the presence of $\mathrm{Pd}(0)$ cataly st. the desired product was obtained in $80 \%$ (entry 1). transCinnamyl methyl carbonate was treated with 3-bronocyclohexene and indium to provide 3-trons-cinnanyl cyclohexene and 3 -(l'-phenyl-2'-propenyl)-l-cyclohexene in $83 \%$ yield (isomeric ratio $=1: 1$ ) which were produced from the proximal and distal attack of indium reagent to the oxygen substituent (entry 3). The reaction of trans-cimamyl methyl carbonate with $\gamma$ ethoxycarbonyl allylindium gave 4ethoxycarbonyl-1-pheny 1-1.5-hexadiene in $44 \%$ y ield due to low nucleophilicity of the stabilized indium reagent (entry 4). Although allyl acetates are commonly used for the various types of $\mathrm{Pd}$-catalyzed substitution reactions. the reactions of allyl acetate with ally lindium did not proceed. Allyl carbonates derived from phenyl vinyl ketone (entries 5-7) and chalcone (entries 8-10) produced the desired 1.5dienes in good yield under the present conditions. Although the methyl carbonate from 1-phenyl-4-penten-3-ol and geraniol reacted with allyl halide $(\mathrm{Br}$ and $\mathrm{I})$ and indium. the desired product was not obtained and a complicated TLC was obtained

Reactions of Allyl Carbonates with in situ Generated Propargylindiums from Indium and Propargyl Halides. On the bases of allylic substitution reactions. we studied reactions of trons-cinnamyl methyl carbonate with in situ generated propargylindium reagent derived from propargyl bromide and indium. The results are summarized in Table 2 .
THF was the solvent of choice among the reaction media tested (entries $4 v 5$ ). Of the catalytic systems examined, the best results were obtained with $2 \mathrm{~mol} \%$ of $\mathrm{Pd}_{2} \mathrm{dba}_{3} \mathrm{CHCl}_{3}$ and $16 \mathrm{~mol} \%$ of $(\sigma \text {-Tolyl })_{3} \mathrm{P}$ in the presence of $\mathrm{LiCl}$ as an additive in THF at $65^{\circ} \mathrm{C}$ for $\mathrm{l} h$ under a nitrogen atmosphere to furnish regioselectively trans-6-phenyl-5-hexen-l-yne in

Table 2. Reaction optimization of propargy lic substitution reactions ${ }^{a}$

\begin{tabular}{|c|c|c|c|c|c|c|c|c|}
\hline \multirow{2}{*}{ Entry } & 1 & 2 & $\ln$ & Additive & \multirow{2}{*}{ Solvent } & \multirow{2}{*}{$\begin{array}{l}\text { Temp } \\
\left({ }^{\circ} \mathrm{C}\right)\end{array}$} & \multirow{2}{*}{$\begin{array}{l}\text { Time } \\
(\mathrm{hr})\end{array}$} & \multirow{2}{*}{$\begin{array}{l}\text { Yield } \\
(\%)^{4}\end{array}$} \\
\hline & \multicolumn{4}{|c|}{ (equiv) } & & & & \\
\hline I & 1 & 1.5 & 1 & & THF & 65 & 18 & 0 \\
\hline 2 & I & 1.5 & 1 & & DMF & 100 & 18 & 0 \\
\hline 3 & I & 3 & 2 & & THF & 65 & 18 & 0 \\
\hline 4 & 1 & 1.5 & 1 & $\mathrm{LiCl}$ & THF & 65 & 18 & $71(23)$ \\
\hline 5 & I & 1.5 & 1 & $\mathrm{LiCl}$ & DMF & 100 & 15 & 0 \\
\hline $6^{c}$ & 1 & 1.5 & 1 & $\mathrm{LiCl}$ & THE & 65 & 18 & $58(39)$ \\
\hline 7 & 1 & 3 & 2 & $\mathrm{LiCl}$ & THF & 65 & 18 & $78(16)$ \\
\hline $8^{d}$ & 1 & 1.5 & 1 & $\mathrm{LiCl}$ & THF & 65 & 18 & $82(15)$ \\
\hline $9^{d}$ & 1 & 3 & 2 & $\mathrm{LiCl}$ & THF & 65 & 1 & $95(92)^{f}$ \\
\hline
\end{tabular}

Reaction performed in the presence of 1 mol ${ }^{\circ} 0$ of $\mathrm{Pd}_{2} \mathrm{dba}_{3} \mathrm{CHCl}_{3}$ and 8 mol ${ }^{0}$ o of $(o \text {-Tolyl })_{3} \mathrm{P}$. unless otherwise noted. "GC yields were obtained on the basis of an intemal standard (dodecane). Numbers in parenthesis indicate recovered GC vield of starting material. "4 mol o of $\mathrm{Pd}\left(\mathrm{PPl}_{3}\right)_{4}$ was ued d $2 \mathrm{~mol}^{\text {a o of }} \mathrm{Pd}_{2} \mathrm{dba}_{3} \mathrm{CHCl}_{3}$ and $16 \mathrm{~mol}$ o of $\left(o-\mathrm{Tol}_{1}\right)_{3} \mathrm{P}$ was used. ${ }^{~ I s o l a t e d ~ y i e l d . ~}$ 
Table 3. Pd-catalyzed propargylic substitution reactions of allyl carbonates with propargylindium reagents"

\begin{tabular}{|c|c|c|c|c|c|}
\hline Entry & Carbonates & Propagyl Halides & Time (hr) & Products & Yield $(\%)^{b}$ \\
\hline 1 & $\mathrm{OCO}_{2}$ & $\mathrm{Br}$ & 1 & & 92 \\
\hline 2 & & & 3 & & 74 \\
\hline 3 & & & 4 & & 72 \\
\hline 4 & & & 2 & & 88 \\
\hline 5 & & & 5 & & 65 \\
\hline 6 & & & 10 & & 63 \\
\hline 7 & & & 1 & & $88(1: 1)^{4}$ \\
\hline 8 & & & 1 & & $81(1: 2 t$ \\
\hline 9 & & $\mathrm{Br}$ & 3 & & 78 \\
\hline 10 & & & 1 & & 85 \\
\hline
\end{tabular}

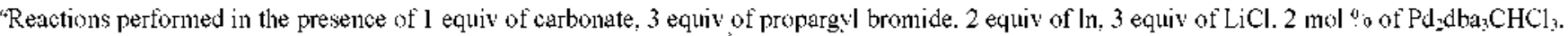
and 16 mol on of $\left(0-\mathrm{Tol}_{\mathrm{l}} 1\right)_{3} \mathrm{P}$ in THF at $65^{\circ} \mathrm{C}$. unless otherwise noted. "Isolated yields. "Isomeric ratio.

$92 \%$ yield via proximal attack of indium reagent (entry 9). No allenic substitution product is formed in any reactions. The use of lithium chloride was critically important for successful reactions (entries 3 vs 9). Also propargy lindium reagent obtained from the reaction of 2 equiv of indium with 3 equiv of propargyl bromide gave the best result as a coupling partner (entries $8 v s$ ).

With these results in hand trans-cimnamyl methyl carbonate reacted with organoindium reagent derived from 3-bromo-1-butyne and indium to give trans-3-methyl-6phenyl-5-hexen-1-y'ne in 74\% y ield wo proximal attack to the oxygen substitution (entry 2 in Table 3). trans-3.6Diphenyl-5-hexen-1-yne was regioselectively produced in $72 \%$ yield in case of 3-bromo-3-phenyl-1-propyne (entry 3 ). Treatment of the methyl carbonate from 1-phenyl-2-propen1-ol with propargy lindium reagents gave the desired product via distal attack due to the steric hindrance (entry 4). Organoindium reagents in situ generated from 3-bromo-1butyne and 3-bromo-3-phenyl-1-propyne and indium produced 1.5 -enynes in $65 \%$ and $63 \%$ yields. respectively (entries 5 and 6). Reaction of methyl carbonate of trans-1phenyl-1.4-pentadien-3-ol with propargylindium reagent provided trans-6-phenyl-4-viny 1-5-hexen-1-yne and trons- 4-phenyl-5,7-octadien-1-yne in $88 \%$ yield (isomeric ratio $=$ $1: 1$, entry 7). Subjecting this carbonate to 3-bromo-1butyne and indium afforded a $27 \%$ yield of trans-3-methyl6-phenyl-4-viny l-5-hexen-1-yne and a $54 \%$ y ield of trans-3methyl-4-phenỵl-5.7-octadien-1-yne (entry 8). Contrary to results above, when methyl carbonates of geraniol and 1vinyl-1-nonanol were treated with propargylindium. 1.3dienes were produced via $\beta$ hydride elimination (entries 9 and 10 ).

Although the mechanism of the reaction of allylindiums and propargylindiums with allyl carbonates in the presence of $\mathrm{Pd}(0)$ catalyst is not clear at the present moment. we assume that organoindium reagents play the similar role to soft nucleophiles of Trost-Tsuji reaction. ${ }^{1}$ This and other plausible mechanistic pathways are under investigation.

In conclusion. we have demonstrated that allylindium and propargylindium reagents in situ generated from the reaction of indium with allyl halides and propargyl halides could participate in $\mathrm{Pd}$-catalyzed substitution reactions of allyl carbonates to produce 1.5 -dienes and 1.5 -enynes. $\beta$-Hydride elimination products were produced in case of carbonates having $\beta$-hydrogens. Because organoindium reagents derived from allyl and propargyl halides and indium have previously 
not been applied to Pd-catalyzed substitution reactions of carbonates, these results should provide more opportunities for the development of new $\mathrm{C}-\mathrm{C}$ bond forming reactions.

\section{Experimental Section}

Typical Experimental Procedure for Allylic Substitution Reactions. To a solution of $\mathrm{Pd}_{2} \mathrm{dba}_{3} \mathrm{CHCl}_{3}(5.2 \mathrm{mg}$, I $\mathrm{mol} \%$ ) and tri-o-tolylphosphine ( $12.2 \mathrm{mg}, 8 \mathrm{~mol} \%$ ) in THF $(1 \mathrm{~mL}$ ) was added trons-cinnanyl methyl carbonate $(96 \mathrm{mg}$. $0.5 \mathrm{mmol}$ ) at room temperature under a nitrogen atmosphere. After $15 \mathrm{~min}$. allylindium reagent in sin generated from allyl bromide (91 $\mathrm{mg}, 0.75 \mathrm{mmol}$ ) and indium (57 $\mathrm{mg} .0 .5$ mmol) in THF ( $1 \mathrm{~mL}$ ) was added and the mixture was stirred at $65^{\circ} \mathrm{C}$ for $24 \mathrm{~h}$. The reaction mixture was quenched with saturated aqueous $\mathrm{NaHCO}_{3}$. The aqueous layer was extracted with ether $(3 \times 15 \mathrm{~mL})$. and the combined organic layers were washed with water and brine, dried with $\mathrm{MgSO}_{4}$. filtered and concentrated under reduced pressure. The residue was purified by silica gel column cluromatography using n-hexane to give troms-1-phenyl-1.5-hexadiene (71 mg. 90\%): ${ }^{1} \mathrm{H} \mathrm{NMR}\left(\mathrm{CDCl}_{3}, 400 \mathrm{MHz}\right) \delta 7.34(2 \mathrm{H}, \mathrm{d}, J=$ $7.4 \mathrm{~Hz}) .7 .29(2 \mathrm{H} . \mathrm{t} . J=7.9 \mathrm{~Hz}), 7.19(\mathrm{lH}, \mathrm{t} . J=7.1 \mathrm{~Hz})$. $6.41(\mathrm{lH} . \mathrm{d}, J=15.9 \mathrm{~Hz}), 6.23(1 \mathrm{H}, \mathrm{dt} . J=15.7,6.6 \mathrm{~Hz})$. 5.88 (lH. tt. $J=10.4 .6 .6 \mathrm{~Hz}) .5 .06(1 \mathrm{H}, \mathrm{d}, J=17.2 \mathrm{~Hz})$. 4.99 (lH. d, $J=9.7 \mathrm{~Hz}$ ). $2.33-2.23(4 \mathrm{H}, \mathrm{m}):{ }^{13} \mathrm{C}$ NMR $\left(\mathrm{CDCl}_{3}, 100 \mathrm{MHz}\right) \delta$ 138.1. 137.8. 130.2, 130.1, 128.5 . 126.9. 125.9. 114.9. 33.6. 32.4: HRMS (EI) calcd for $\mathrm{C}_{1}=\mathrm{H}_{3}$ 158.1096. found 158.1095 .

Typical Experimental Procedure for Propargylic Substitution Reactions. To a solution of $\mathrm{Pd}_{-} \mathrm{dba}_{3} \mathrm{CHCl}_{3}(10.4$ mg. $2 \mathrm{~mol} \%$ ). tri- 0 -tolylphosphine (24.4 mig. $16 \mathrm{~mol} \%$ ) and lithium chloride $(63.6 \mathrm{mg} .1 .5 \mathrm{mmol})$ in THF (1 mL) was added troms-cinnamyl methyl carbonate (96 mig, $0.5 \mathrm{nmmol}$ ) at room temperature under a nitrogen atmosphere. After 10 min, propargylindium reagent in sini generated from propargyl bronide (166 $\mathrm{mg} .1 .5 \mathrm{~mm}$ ol) and indium (114.8 $\mathrm{mg}$. $1 \mathrm{mmol})$ in THF (1.5 mL) was added and the mixture was stirred at $65^{\circ} \mathrm{C}$ for $1 \mathrm{~h}$. The reaction mixture was quenched with saturated aqueous $\mathrm{NaHCO}_{3}$. The aqueous layer was extracted with ether $(3 \times 15 \mathrm{~mL})$, and the combined organic layers were washed with water and brine. dried with $\mathrm{MgSO}_{4}$. filtered and concentrated under reduced pressure. The residue was purified by silica gel column chromatographỵ using $n$-hexane to give trans-6-phenyl-5-hexen-1-yne (72 mg. 92\%): $\left.{ }^{1} \mathrm{H} \mathrm{NMR} \mathrm{(400} \mathrm{MHz,} \mathrm{CDCl}_{\mathfrak{j}}\right) \delta 7.4-7.1(5 \mathrm{H} . \mathrm{m})$. $6.46(1 \mathrm{H} . \mathrm{d}, J=15.9 \mathrm{~Hz}), 6.26(1 \mathrm{H}, \mathrm{dt} . J=15.8,6.5 \mathrm{~Hz})$. $2.5-2.3(4 \mathrm{H}, \mathrm{m}), 1.99(1 \mathrm{H}, \mathrm{t} . J=2.5 \mathrm{~Hz}){ }^{13} \mathrm{C}$ NMR $\left(\mathrm{CDCl}_{\hat{j}}\right.$. $100 \mathrm{MHz}) \delta 137.8,131.6 .128 .9,128.8,127.6 .126 .5 .84 .2$. $69.3,32.4 .19 .1$.

Acknowledgements. This work was supported by the Korea Research Foundation Grant (KRF-2001-005-D20012). NMR and mass data were obtained from the central instrumental facility in Kangwon National University.

\section{References}

1. (a) Tsuji. I. Palladim Reagents and Catahyts: Tohn Wiley \& Sons: Chichester. 1995: pp 290-422. (b) Godleski. S. A. In Conprehensive Organic Symhesis: Trost. B. M.: Fleming. I.. Eds.: Pergamon Press: Oxford. 199l: Vol. 4, p 585. (c) Tsuji. J. Tetrahedron 1986, 42. 4361. (d) Trost. B. M. Tetrahedron 1977. 33. 2615. (e) Heumann. A. In Transition Metals for Organic Smlhesis: Beller. M. Bolm. C.. Eds.: Wiley-VHC: Weinheim. 1998: Vol. 1. p 251.

2. (a) Trost. B. M. Acc. Chent. Res. 1980. 13. 385. (b) Wade. P. A.: Morrow, S. D.: Hardinger. S. A. J. Org. Chem 1982, 47. 365. (c) Tsuji, J. Pun Appl Chem. 1986. 58. 869. (d) Tsuji, J.; Minami. L. Acc. Chem. Res. 1987. 20. 140.

3. (a) Castanet. Y.: Petit. T. Tetrahedron Lett. 1979. 20. 3221. (b) Temple. T. S.: Schwartz. J. J. Am. Chent. Soc. 1980. 102.7381. (c) Hayashi. T.: Konishi. M.: Yokota. K.: Kumada. M. Chent. Commun 1981, 313. (d) Matsushita, H, Negishi, E. J. Am. Chem. Soc. 1981, 103, 2882. (e) Godlesk, S. A.: Gundlach, K. B.: Ho, H. Y: Keinan. E; Frolow, F. Organometallics 1984. 3. 21. (f) Hayashi. T: Konishi. M.: Kumada. M. Chen. Conmum. 1984. 107.

4. (a) Trost. B. M.: Keinan1. E. Tetrohedon Lett. 1980. 21. 2595. (b) Godschalx, J; Stille. J. K. Tetrohedron Lett. 1980. 21, 2599. (c) Goliaszewski, A.: Schwartz. J. J. Am. Chem. Soc. 1984. 106. 5028. (d) Goliaszewski, A.; Schwartz. J. Tetrahedron 1985. 41. 5779. (e) Trost. B. M.: Van Vranken. D. L. Chent. Rev 1996. 96. 395. (f) Trost. B. M.: Crawley. M. L. Chent. Rer: 2003. 103. 2921.

5. (a) Farina. V.: Krishnamurthy. V.: Scott. W. T. The Stille Reaction: Wiley: New York, 1998. (b) Stille. J. K. Angew: Chem. Int. Ed. Engl. 1986. 25. 508. (c) Stille, J. K. Pure Appl. Chem. 1985. 57. 1771. (d) Mitchell. T. N. Synthesis 1992. 803. (e) Farina, V: Krishnamulhy. V: Scott. W. T. Org. React. 1997. 50. 1. (f) Pereyre. M.: Quintard. I.: Rahm. A. Tin in Organic Stmhesis: Butterwolths: London. 1987.

6. Geissler. H. In Transition Metals for Organic Snmhesis. Beller. M., Bolm. C., Eds: Wiley-VCH: Weomheim, 1998: Chapter 2.10 .

7. (a) Lee. P. H.: Lee. K.: Sung. S.-Y.: Chang. S. J. Org. Chem. 2001. 66. 8646. (b) Lee. P. H.: Lee. K.: Kim. S. Org. Lett. 2001. 3. 32015 (c) Iwasawa. N.: Miura. T.: Kiyota. K.: Kusama. H.: Lee. K.: Lee. P. H. Org. Lett. 2002, 4463 (d) Lee, P. H.: Seomoon, D. Lee. K: Heo. Y. J. Org. Chem 2003, 68, 2510 . (e) Mura. T.: Kivota, K: Kusama. H; Lee. K; Kim. H; Kim. S.; Lee. P. H.; Iwasawa. N. Org. Lett. 2003. 5. 1725. (f) Lee. K.: Kim. H.: Mitra. T.: Kiyota. K.: Kusama. H.: Kim. S.: Iwasawa. N.: Lee. P. H. J. dim. Chent Soc. 2003. 125.9682 (g) Damle. S. V: Seomcon. D.: Lee. P. H. J Org. Chem. 2003, 68. 7085. (h) Lee. P. H.; Kim, S.: Lee. K: Seomoon. D.: Kim. H.: Lee, S.; Kim, M.; Han, M; Noh, K: Livinghouse, T. Org. Lett. 2004. 6. 4825. (i) Lee. P. H.: Kim, H. Lee. K.: Seomoon. D.: Kim. S.: Kim. H.: Kim. H.: Lee. M.: Shim. E.: Lee. S.: Kim. M.: Hant. M.: Noh. K.: Sridhar. M. Bull. Konean Chent. Soc. 2004. 25. 1687.

8. (a) Lee, P. H.; Sung, S.-Y.: Lee, K. Org. Lett 2001. 3. 3201. (b) Lee. P. H.: Sung. S.-Y.; Lee, K.: Chang, S. Synlett 2002. 146. (c) Lee. K.: Seomoon, D.; Lee, P. H. Angew: Chem, Int Ed $\mathbf{2 0 0 2}$, it. 3901 . (d) Lee. K.: Lee. T.: Lee. P. H. J. Org. Chent 2012. 67. 8265. (e) Lee. P. H.: Lee. S. W.: Lee. K. Org. Lett. 2003.5 .1103$. (f) Lee. P. H.: Lee. S. W.: Seomoon. D. Ong. Lett. 2003. 5. 4963. (g) Lee, S. W.: Lee, K.: Seomoon, D.: Kim. S: Kim. H.: Kim. H: Shim. E.; Lee. M.: Lee, S.: Kim, M: Lee. P. H. J. Org Chem. 2004. 69. 4852. (h) Lee. P. H.: Seomoon, D.: Lee. K. Kim. S: Kim. H.: Kim. H.: Shim. E.: Lee. M.: Lee. S.: Kim. M.: Sridhar. M. .Ac: Sinh. Catal 2004. 3+6. 1641. (i) Lee. P. H.: Seomoon. D.: Lee. K. Org. Lett. 2005. 7. 343. 